\title{
Mobile-customer relationship management and its effect on post-purchase behavior: The moder- ating of perceived ease of use and perceived usefulness
}

\author{
Jassim Ahmad Al-Gasawneha ${ }^{a}$, Batool Al Khoja ${ }^{a^{*}}$, Marzouq Ayed Al-Qeed ${ }^{b}$, Nawras M. Nusairat ${ }^{a}$, \\ Qais Hammouria and Marhana Mohamed Anuarc
}

${ }^{a}$ Department of Marketing, Faculty of Business, Applied Science Private University, 11931 Amman, Jordan

${ }^{b}$ College of Communication and Media, Al Ain University, 64141 Al Ain, United Arab Emirates

${ }^{c}$ Department of Marketing, Faculty of Business, Economics and Social Development, Universiti of Malaysia Terengganu, 21030 Kuala Nerus, Terengganu, Malaysia

\section{H R O N I C L E}

Article history:

Received: July 22, 2021

Received in revised format: September 16, 2021

Accepted: December 15, 2021

Available online: December 15, 2021

Keywords:

Mobile CRM

Perceived Ease of Use

Usefulness

Post purchase

Jordan

\section{A B S T R A C T}

Customers' online shopping intentions have not changed in response to technological advancements, making it difficult for businesses and marketers to invent new strategies to maintain long-term relationships with customers and encourage them to repurchase despite unprecedented technological advancements around the world. Following these issues, the current study investigated how M-CRM, Perceived Ease of Use, and Perceived Usefulness influenced Post-Purchase Behavior, as well as how Ease of Use and Perceived Usefulness mediated the relationship between M-CRM and Post-Purchase Behavior. The study introduces the Unified Theory of Acceptance and Use of Technology as a theoretical framework to accomplish this goal. The 239 responses were evaluated using Smart Partial Least Squares after the data was obtained from a random sample of Jordanian consumers. M-CRM, as well as Perceived Ease of Use and Perceived Usefulness, had a beneficial influence on post-purchase behavior, according to the data. Perceived Usefulness and Ease of Use The relationship between M-CRM and Post-Purchase Behavior was impacted by usefulness. Companies might use these facts to develop a marketing strategy for Jordanian customers.

\section{Introduction}

In the internet digitalized world, repurchasing an online service equals a returning customer in the real world, and reusing an online service means that the customer has used the service previously (Kianpour et al., 2017; Wang et al., 2018). As per recent studies, using an online service increases both short- and long-term profitability (Saarijärvi et al., 2017; Hammouri et al., 2021a). As a response, online shopping platforms are crucial for businesses to expand and sustain their operations, as well as to create a continual post-purchase effect (Wulfert, 2019; Nusairat et al., 2021). Post-purchase behavioral intention is defined as the future behavior commitment to buy a product or service or the link with a provider when other options are available. Reuse intention and post-purchase behavior are the willingness of the customer to rebuy from the same place, and according to Mouri (2005), Customer satisfaction is an important notion in marketing since it is seen to be a substantial determinant of repeat sales, word-of-mouth, and customer loyalty. Positive post-purchase behavioral intention is the key source of future revenues and is regarded as the most significant managerial component in winning market share. (Jankingthong \& Gonejanart, 2012). In Jordan, companies and organizations compete fiercely in the retail and other industries to increase their ability to retain customers by increasing the possibility that they will make another purchase, whether electronic or traditional (Al-Gasawneh et al., 2020; Shaon \& Rahman, 2015).

* Corresponding author.

E-mail address: batoolskh@gmail.com (B. A. Khoja)

(C) 2022 by the authors; licensee Growing Science, Canada. doi: $10.5267 /$ j.ijdns.2021.12.010 
Al-Gasawneh et al. (2020) suggested that firms located in Jordan need to develop its services to motivate their customers to re-use their e-services. According to related studies, developing and maintaining long-term relationships with consumers is critical for service organizations to have a competitive advantage. (Raajpoot \& Ghilni-Wage, 2019). One of the most significant marketing advances has been the rise of electronic customer relationship management (E-CRM) systems, which are primarily geared to generate and manage long-term client connections. Companies today are dealing with a significantly new component, the process of relationship building between a firm and its clients, which boosts lifetime value and profitability. Per the preceding debate, new strategies such as M-CRM could be utilized to start and sustain a continuous, longterm connection that is profitable and mutually trusting. (Hammouri et al., 2021b; San-Martín, et al., 2016) considers retail channel through mobile applications a powerful tool in relationship marketing that allows for the formation of a link with the customer, which encourages a rise in sales and improves the company's total profitability. According to Grover (2011), Customers must be able to reach the E-CRM system via a variety of touch points, including face-to-face contact, fax, VoIP, web forms, e-mail, web self-help, and phone, and user systems must be allowed the access as well, via a variety of client systems, including personal digital assistants (PDAs), personal computers, and mobile phones. Mobile applications provide services and exclusive app promotions that entice customers to return again and again. Researchers have begun to focus on downstream components of this, (Jankingthong \& Gonejanart, 2012) makes a specific mention to the use of marketing through cell-phones, particularly the usage of applications to improve consumer pleasure and loyalty, yet does not present any evidence. According to Al-Momani and Mohd Noor (2009), there might be an impact of ease of use on E-CRM performance, while (Arahita \& Hatammimi, 2015) suggested that perceived ease of use might affect the intention to use mobile banking services again. Meanwhile (Awasthi \& Sangle, 2013; Alghasawneh et al., 2021) suggested that Perceived usefulness could be determined as a predictor of behavioral intention to utilize Mobile Banking Service (MBS), which is M-CRM in the banking sector, and (Li et al., 2012) revealed that perceived usefulness could affect the intention to reuse.

As per some studies, it was found that post-purchase behavior might need development in Jordan, and based on recommendations, it can be improved through implementing M-CRM. In addition, it was found that the relationship between M-CRM and post-purchase behavior was unstable, As a result, the two moderators of perceived utility and perceived ease of use were added. Therefore, the current study will investigate the moderating role of (perceived ease of use and perceived usefulness) on the relationship between Mobile-Customer Relationship Management and Post Purchase Behavior.

\section{Theoretical background}

\section{$2.1 M-C R M$}

In theory, Sangle \& Awasthi (2011) referred to mobile CRM as traditional CRM but integrated by a mobile device (such as a mobile phone or PDA). While (Liljander et al., 2007) identified mobile CRM as any form of Customer relationship management, which includes interactive interaction between a business and a customer via a smartphone. The quality of the software, the design of the display and services, and the customers' appraisal of the service content in proportion to any additional charges associated with utilizing it characterize the efficiency of a mobile CRM program. Even though in the past, consumers were wary about using mobile services. Future mobile applications are expected to have a major impact on customer acquisition and retention by providing additional services and benefits to clients (Almajali et al., 2021; AlGasawneh et al., 2021). On another note, the primary attribute and added value to mobile service clients is frequently known as the capacity to access services whenever and wherever needed.

Mobile Customer Relationship applications are utilized to actively communicate with customers from anywhere in this world, providing them with access to the same services as they would through a fixed Internet connection or through personal contact (Hammouri et al., 2020). One benefit that is frequently emphasized is that businesses may provide clients with location-specific information and personalized service. Mobile CRM is also critical for improving sales performance in businesses. It has the potential to improve the adoption of other sales technology, such as traditional CRM. From the standpoint of a salesperson, mobile CRM has an impact on collaboration and relationship performance, as well as how collaboration moderates that relationship. Due to its ease of use and functionality, M-CRM allows sales professionals to use CRM technology more efficiently from a mobile application (Rodriguez \& Boyer, 2020). The current study handles this variable to cover its service content and usability, comfort and security, mobile feedback, and brand assets.

\subsection{Perceived Ease of Use (PEOU)}

The perceived ease of use influences certain attitudes related to the use of innovation (Davis, 1989). Using a specific technology would not need any physical or mental effort. The user may accept that a specific innovation is useful, yet the user may realize that it is difficult to utilize while using the mobile (Hussain et al., 2016). This can be an obstacle to capture customers to use M-CRM or any mobile application. According to Choi et al., (2017), personalization and ease of use are the two critical factors for the success of a mobile application. The other is used to characterize how users perceive the quality of the system. (Hamid et al., 2016) mentioned that individuals will be willing to understand a system's features and continue to use it if it is relatively simple to use. Users should be able to utilize and navigate around mobile applications quickly and easily. This feature can assist users in deciding if an app is easy to use or difficult to use. The current study handles this variable to know the extent to which using M-CRM applications can be easy, interaction with it is clear and simple, and the easiness to become skillful at using it. 


\subsection{Perceived Usefulness (PU)}

The degree to which a person believes that employing a specific technology would improve job performance is referred to as perceived usefulness, Davis (1989). Previous research has shown that perceived usefulness and perceived ease of use are important predictors of future users' attitude and behavioral intention towards using a system. Studies have also found that online applications that are clear, simple to use, and easy to navigate add a significant benefit to the creation of a positive attitude toward utilizing this online application (Heijden, 2003). A study proposed that perceived usefulness has a direct impact on usage intention (Heijden, 2003). The current study handles this variable to study its effect on M-CRM through testing its usefulness in daily life, the ability to perform tasks more easily, and the level of productivity achieved.

\subsection{Post-Purchase Behavior}

According to Jankingthong and Gonejanart (2012), post-purchase behavioral intention is considered as the future behavior promise to purchase a product or service or the relationship with a company when other options are available. On another side, post-purchase behavior is referred to as the behavior shown by the customers after buying the product. Whether the customer is previously satisfied or dissatisfied. But many times a customer goes through cognitive dissonance. Repurchase occurs if the consumer is satisfied, enabling the business to create additional profit through customer retention. When a consumer is disappointed, he either stops buying or spreads negative word of mouth, which is a problem (Panda, 2014; Halimi et al., 2021; Tandon et al., 2018). Based on the reinforcement theory, pleasant outcomes tend to be repeated, but negative results are less likely to be repeated. So, to encourage customers to return for further purchases or visits, favorable attitudes must be developed in order to increase their satisfaction. In turn, satisfaction leads to positive post-purchase behavioral intentions. In (Born \& Sirmans, 2019) article on regret in health insurance, they discussed the importance of addressing regret in post-purchase behavior while examining other factors including the ability to afford, self-evaluated risk, and pleasure with health plans. Regret in post-purchase behavior can be a factor that makes the business lose a customer. The current study will handle this variable to examine the impact of willingness to use services again in the future, recommendation of services to others, and continuous use of service.

\section{Hypothesis development}

\subsection{M-CRM and Post-Purchase Behavior}

According to Gani and Maung (2020), the primary objective of developing an application and software was to provide customers with simple access to information about sales and technical decisions. The study showed a major positive impact of mobile application on repurchase intention. Another study by Lee et al. (2008) and Alalwan (2020) showed a positive significant effect of mobile applications on repurchase intention. On the other hand, a study by (Liljander, Polsa \& Forsberg, 2007) showed that M-CRM had no relationship with post-purchase behavior because customers were not ready to fully embrace new mobile applications. Based on the previous studies the following hypotheses is developed:

\section{$\mathbf{H}_{1}$ : M-CRM has a positive impact on Post-Purchase Behavior.}

\subsection{Perceived Ease of use and Post-Purchase Behavior}

The results of a study conducted by Badir and Andjarwati (2020) showed that there was a positive significant effect of ease of use on purchasing decisions. This explains when a system is more straightforward, it will encourage buying decisions, as it is more convenient to use. Kotler \& Keller (2012) explain that purchasing decisions are the ways in which people, groups, or organizations pick, buy, consume, and employ things, services, concepts, and experiences in order to satisfy desired demands. Basically, Post-purchase decision is extremely related to purchase decision, it is differentiated when the customer already made a purchase and gained a certain view and judgment on the purchased service/product and whether they are willing to repurchase from the same company again. In a study conducted by (Arahita \& Hatammimi, 2015) it resulted that the perceived ease of use positively affects the intention to reuse mobile Bank Central Asia. It demonstrates that if the mobile application is simple to use and does not necessitate significant effort, customers will return to use the service. Based on the previous studies the following hypotheses is developed:

\section{H2: Perceived Ease of use has a positive impact on Post-Purchase Behavior.}

\subsection{Perceived Usefulness effect on post-Purchase behavior}

According to an empirical examination by Zhou (2011), it was concluded that perceived usefulness had a positive effect on purchase intention, the study suggests providing personalized and dependable services to promote user adoption and usage because of its effect. Post-purchase intention and purchase intention are about the decision-making that studies the reason for a particular brand by consumer, although, post-purchase is related to the intention of purchase after making a previous one.

In an article by Theocharidis et al. (2020), studying factors affecting booking a hotel room through social media, it said that perceived usefulness positively affects the intention to book online. According to (Cha, 2009; Ogunsola, 2005), when more people perceive shopping services on social media platforms as beneficial, they are more likely to shop using them. The 
same can be applied to M-CRM applications, as they are software packages designed mainly for customers to use and get the service they want. Furthermore, an empirical study on behavioral intention to reuse e-learning systems in rural China by (Li et al., 2012) revealed that perceived usefulness has a positive direct effect on the intention to reuse. Based on the previous studies the following hypotheses is developed:

$\mathbf{H}_{3}$ : Perceived Usefulness has a positive impact on post-Purchase behavior.

\subsection{The moderating role of Ease of Use on the relationship between M-CRM and Post-Purchase Behavior}

Perceived Ease of use and M-CRM were found to have a positive significant relationship in a study conducted by Sangle and Awasthi (2011), the findings showed that the highest predictive power for intention to use mobile CRM services belonged to perceived utility value followed by ease of use. Another study proved that there are three antecedent variables that have a significant relationship with E-CRM performance, these factors are e-service quality, ease of use and usability. (Al-Momani \& Mohd Noor, 2009; Sarwar \& Soomro, 2013). E-CRM or electronic customer relationship management includes all the CRM functions with the use of the net settings that are intranet, extranet and internet. Electronic CRM is related to all kinds of managing relationships with customers making use of information technology (Ahmed et al., 2019). So based on the previous definition, M-CRM is a side of E-CRM that is used through mobile devices as a medium. Further positive significant relationship was found between ease of use and mobile applications in a study by (Leong et al., 2011). Perceived ease of use and post-purchase behavior were found to have a positive significant relationship. According to the previously mentioned studies that studied Ease of use and post-purchase behavior, it showed that the results of a study conducted by Badir and Andjarwati (2020) showed that there was a significant effect of ease of use on purchasing decisions. This explains when a system is more straightforward, it will encourage buying decisions, as it is more convenient to use. Basically, post-purchase decision is extremely related to purchase decision, it is differentiated when the customer already made a purchase and gained a certain view and judgment on the purchased service/product and whether they are willing to repurchase from the same company again. In a study conducted by (Arahita \& Hatammimi, 2015) it resulted that the perceived ease of use positively affected the intention to reuse mobile Bank Central Asia. It demonstrates that if the mobile BCA application is simple to use and does not necessitate significant effort, customers will continue to use the service. According to the previous relationship between M-CRM and post-purchase behavior, the study (Bibi, 2016) found that when there is an inconsistent relationship thus in this case the relationship needs a moderator. Based on the previous studies the following hypotheses is developed:

H4: Ease of use moderates the relationship between M-CRM and post purchase behavior.

\subsection{The moderating role of Perceived Usefulness on the relationship between M-CRM and Post-Purchase Behavior}

Perceived Usefulness and M-CRM were found to have a positive significant relationship by a concept article by Wahab (2011) which successfully and positively justified the importance of perceived usefulness as the main antecedent for ECRM performance in mobile phone services. In a study by (Awasthi \& Sangle, 2013), perceived usefulness was identified to have a positive significant effect on behavioral intention to adopt Mobile Banking Service (MBS), it has been found that users would be ready to utilize mobile banking if they found it to be more beneficial than the other accessible banking solutions. Another result by Shaikh and Karjaluoto (2015) revealed that perceived usefulness is one of the most positive significant drivers of intentions toward using mobile banking applications. Perceived Usefulness and post-purchase behavior were found to have a positive significant relationship, according to an empirical examination by Zhou (2011), it was resulted that perceived usefulness had a positive effect on purchase intention, the study suggests presenting personalized and reliable services to facilitate users' adoption and usage due to its effect. Post-purchase intention and purchase intention are about the decision-making that investigates the reasons why a certain brand is preferred by consumers, although, postpurchase is related to the intention of purchase after making a previous one. In an article by Theocharidis et al. (2020), studying elements affecting booking a hotel room through social media, it said that perceived usefulness positively affects the intention to book online. According to Cha (2009), the more consumers think social media shopping services are beneficial, the more inclined they are to utilize them. The same can be applied to M-CRM applications, as they are software packages designed mainly for customers to use and get the service they want. Furthermore, an empirical study on behavioral intention to reuse e-learning systems in rural China by Li et al. (2012) and Nusairat et al. (2021) revealed that perceived usefulness has a positive direct effect on the intention to reuse. According to the previous relationship between M-CRM and post-purchase behavior, the study (Bibi, 2016) found that when there is an inconsistent relationship thus in this case the relationship needs a moderator. Based on the previous studies the following hypotheses is developed:

\section{H5: Perceived Usefulness moderates the relationship between M-CRM and post purchase behavior.}

\section{Method}

The goal of this study is to contribute by filling a gap by investigating the impact of mobile-CRM on post-purchase behavior in the context of service provision in Jordan, with the moderating effects of usefulness and ease of use on the relationship. For the evaluation, a quantitative approach based on surveys is regarded as suitable. The following articles go through the methods of analysis in greater depth. The survey was conducted using a two-part questionnaire. The first portion of the 
questionnaire comprised demographics (gender, age, income, and frequency of online purchase), whereas the second section included measures of the components included in the study model. The following are the parts of the questionnaire used to evaluate each build: According to Rodriguez and Boyer (2020), the multidimensionality of mobile-CRM was consisted of four components: service content and usability ( 4 items), comfort and security ( 4 items), mobile feedback ( 6 items), and brand assets (5 items). Kuo et al. (2009) suggested that post-purchase behavior be used as a unidimensional variable; Alalwan et al. (2016) suggested that perceived ease of use be used as a unidimensional variable; Alalwan et al. (2016) suggested that perceived usefulness be used as a unidimensional variable, all construction scales are based on a 5-point Likert scale. The study collected measurements of independent and dependent variables from numerous sources to solve the problem of conventional system variance (CMV), and these varied sources were utilized to determine the variables in this study as recommended by (Tehseen, Ramayah \& Sajilan, 2017; Bhattacharya, 2011).

\section{Sampling}

All online shoppers who purchased products or services using mobile applications make up the study's population. In the meanwhile, the data was acquired using an online survey. The survey was sent out to online users using social media sites like Facebook and Instagram. Respondents were also urged to share the information with their coworkers who were interested in online shopping. Because the nature of the investigation emphasizes the reliability of the theoretical conclusions, convenience sampling was utilized in this study (Hafaz Ngah et al., 2020). Respondents were asked to provide a list of the companies from which they obtain services to assess their trustworthiness. Power of analysis was employed to establish the minimal sample size for the inquiry since the study used structural equation modeling using Smart PLS (Hair et al., 2017). The complexity of the model determines the minimal sample size. The minimal sample size for the study's three predictors is 74 , based on a power of 0.8 and a medium impact size as proposed by (Gefen et al., 2011). As a result, the survey was sent to 350 respondents for this study to get as many replies as possible; moreover, the sample size of 350 respondents was sufficient to verify the research model in this study based on the limited sample size generated from power analysis.

\section{Result}

For this study, 180 answers were collected in total. Despite this, 41 people were disqualified because their data was of poor quality (i.e., brief answers and partial data). Therefore, 139 reliable responses had to be examined.

\subsection{Moderating analysis approaches}

The data was analyzed using the partial least squares technique, which allowed for a variety of moderator analysis methods, including the product indicator approach with reflective-reflective construct, which lacks significant statistical power, and a two-stage method using formative indicators (Fassott et al., 2016; Sinisalo et al., 2007). When selecting whether to utilize formative or reflective constructs, the latter is seen to be more suitable when the goal is to know about the importance of the moderator effect (Chin, 2010; Hair et al., 2017). As a result, the moderator influence was studied in this work using a twostage technique centered on existing reflective-reflective structures, eliminating difficulties associated with the product indicator approach's low statistical capability. Before considering the relationship notion, the initial stage required testing convergent and discriminant validity. The product indicator determination helped to incorporate the interaction idea, as well as the predictor and moderator variables, in the second step of creating the structural model's specification. Hair et al. (2017). Because it makes no preconceptions about the kind of variable distribution, the bootstrapping strategy is consistent with PLSSEM in terms of helping analysis. As a result, it is only useful for tiny samples. As a result, in this study, bootstrapping was used to explore the direct influence of the explanatory variables on the endogenous latent variable via the moderating variable (Preacher \& Hayes, 2008; Pothal et al., 2021). As a result, the findings of the moderators as well as the direct relationships were obtained at the same time.

\subsection{Measurement model}

The key variables studied in this study were reuse shopping intention and perceived ease of use and perceived usefulness as first-order constructs, and M-CRM as reflective-reflective structures as second-order construct. M-CRM was evaluated using the factors of Service content and usability, The variables of decision, access, transaction, benefit, and post-benefit convenience were used to evaluate service convenience, whereas the factors of comfort and security, mobile feedback, and brand assets were used to evaluate service convenience. To have a better grasp of key logical and consensus functions, M-CRM and service simplicity were chosen as second-order elements. The second order was utilized to decrease the number of interactions and assumptions to be stated in the structural model, streamlining the PLS direction model and keeping it easier to grasp, as advised by Hair et al. (2016). Meanwhile, in agreement with Becker et al., the plan was implemented in two stages (2012). Therefore, in the first step, the repeating indication approach was utilized to produce first-order scores for first-order constructions. The second phase involves computing the CR. AVE of the second-order contract based on the weighting of the first-order variables (Hulland, 1999).

Hair et al. (2017) used factor loadings, Cronbach Alpha (CA), Composite Reliability (CR), and Average Variance Extracted to verify convergent validity (AVE). Therefore, any item having a loading larger than the prescribed 0.5 was discovered (Table 1). Interestingly, CA and CR values were larger than 0.7 in both constructs, but AVE values were larger than 0.5 , which was similar with Hair et al. (2017). Therefore, the validity of convergent validity was validated. 
Table 1

Measurement Model

\begin{tabular}{|c|c|c|c|c|}
\hline First order Construct & Items & Factor loading & $\mathbf{C R}$ & AVE \\
\hline \multirow[t]{4}{*}{ Service content and usability } & SCU 1 & 0.807 & \multirow[t]{4}{*}{0.939} & \multirow[t]{4}{*}{0.794} \\
\hline & SCU 2 & 0.883 & & \\
\hline & SCU 3 & 0.844 & & \\
\hline & SCU 4 & 0.834 & & \\
\hline \multirow[t]{4}{*}{ Comfort and security } & CS 1 & 0.865 & \multirow[t]{4}{*}{0.961} & \multirow[t]{4}{*}{0.860} \\
\hline & CS 2 & 0.918 & & \\
\hline & CS 3 & 0.941 & & \\
\hline & $\mathrm{CS} 4$ & 0.930 & & \\
\hline \multirow[t]{6}{*}{ Mobile feedback } & MF 1 & 0.833 & \multirow[t]{6}{*}{0.907} & \multirow[t]{6}{*}{0.622} \\
\hline & MF 2 & 0.840 & & \\
\hline & MF 3 & 0.821 & & \\
\hline & MF 4 & 0.791 & & \\
\hline & MF 5 & 0.781 & & \\
\hline & MF 6 & 0.621 & & \\
\hline \multirow[t]{5}{*}{ Brand Assets } & BA 1 & 0.932 & \multirow[t]{5}{*}{0.935} & \multirow[t]{5}{*}{0.779} \\
\hline & BA 2 & 0.843 & & \\
\hline & BA 3 & 0.850 & & \\
\hline & BA 4 & 0.851 & & \\
\hline & BA 5 & 0.863 & & \\
\hline \multirow[t]{3}{*}{ Ease of use } & EOF 1 & 0.765 & \multirow[t]{3}{*}{0.846} & \multirow[t]{3}{*}{0.730} \\
\hline & EOF 2 & 0.854 & & \\
\hline & EOF3 & 0.790 & & \\
\hline \multirow[t]{4}{*}{ Usefulness } & UF 1 & 0.885 & \multirow[t]{4}{*}{0.911} & \multirow[t]{4}{*}{0.723} \\
\hline & UF2 & 0.855 & & \\
\hline & UF 3 & 0.847 & & \\
\hline & UF 4 & 0.868 & & \\
\hline \multirow[t]{3}{*}{ Post purchase } & PP1 & 0.889 & \multirow[t]{3}{*}{0.893} & \multirow[t]{3}{*}{0.747} \\
\hline & PP2 & 0.853 & & \\
\hline & PP 3 & 0.899 & & \\
\hline \multicolumn{5}{|l|}{ Second Order Constructs } \\
\hline \multirow[t]{4}{*}{ M-CRM } & Service content and usability & 0.911 & \multirow[t]{4}{*}{0.914} & \multirow[t]{4}{*}{0.891} \\
\hline & Comfort and security & 0.821 & & \\
\hline & Mobile feedback & 0.915 & & \\
\hline & Brand Assets & 0.893 & & \\
\hline
\end{tabular}

The Heterotrait-Monotrait (HTMT) (Fornell \& Bookstein, 1982) criteria was employed to assess discriminant validity. Discriminant validity was confirmed because the HTMT values obtained were less than 0.90 (Sekaran \& Bougie, 2016; Henseler, Ringle \& Sarstedt, 2015). Additional information on this topic may be found in Table 2.

Table 2

Discriminant validity (HTMT)

\begin{tabular}{|c|c|c|c|c|c|c|c|c|}
\hline & $\mathrm{SCU}$ & $\mathrm{CS}$ & MF & $\mathbf{B A}$ & M-CRM & EOF & UF & $\mathbf{P P}$ \\
\hline \multicolumn{9}{|l|}{ SCU } \\
\hline CS & 0.574 & & & & & & & \\
\hline MF & 0.836 & 0.533 & & & & & & \\
\hline $\mathbf{B A}$ & 0.083 & 0.557 & 0.794 & 0.151 & & & & \\
\hline M-CRM & 0.765 & 0.812 & 0.622 & 0.415 & & & & \\
\hline EOF & 0.795 & 0.759 & 0.613 & 0.054 & 0.860 & & & \\
\hline UF & 0.813 & 0.537 & 0.517 & 0.129 & 0.650 & 0.636 & & \\
\hline PP & 0.833 & 0.622 & 0.780 & 0.257 & 0.720 & 0.676 & 0.655 & \\
\hline
\end{tabular}

The consistency and applicability of the measuring scale utilized for this project were all confirmed by the built study findings, as well as the related convergent and discriminant validity (Tables 1 and 2).

\subsection{Structural model}

The structural model was assessed using several metrics, according to Hair et al. (2016), including R2, beta, t-values from bootstrapping with a 1,000 resample, predictive significance Q2, and VIF, as shown in Fig. 3.

Table 3

Testing direct relationships

\begin{tabular}{lccccccccc}
\hline & Path & St, $\beta$ & St. d & R $^{2}$ & $\mathrm{Q}^{2}$ & $\mathrm{~F}^{2}$ & VIF & T-value & P-value \\
\hline H1 & M-CRM $\rightarrow$ PP & 0.311 & 0.133 & 0.477 & 0.540 & 0.670 & 2.187 & 2.338 \\
H2 & EOF $\rightarrow$ PP & 0.544 & 0.180 & & 0.000 & 2.121 & 3.022 \\
H3 & UF $\rightarrow$ PP & 0.318 & 0.103 & & 0.000 & 0.465 & 2.136 & 3.087 \\
\hline
\end{tabular}


Table 4

Testing moderating (interaction) effect

\begin{tabular}{lcccccccc}
\hline & Path & St, $\beta$ & St. d & T-value & R $^{2}$ & LL (5\%) & UL (95\%) & P-value \\
\hline H4 & M-CRM - PP* EOF & 0.301 & 0.077 & 3.909 & 0.491 & 0.086 & 0.331 \\
H5 & M-CRM - PP* UF & 0.219 & 0.056 & 3.910 & 0.331 & 0.072 & 0.163 & 0.000 \\
\hline
\end{tabular}
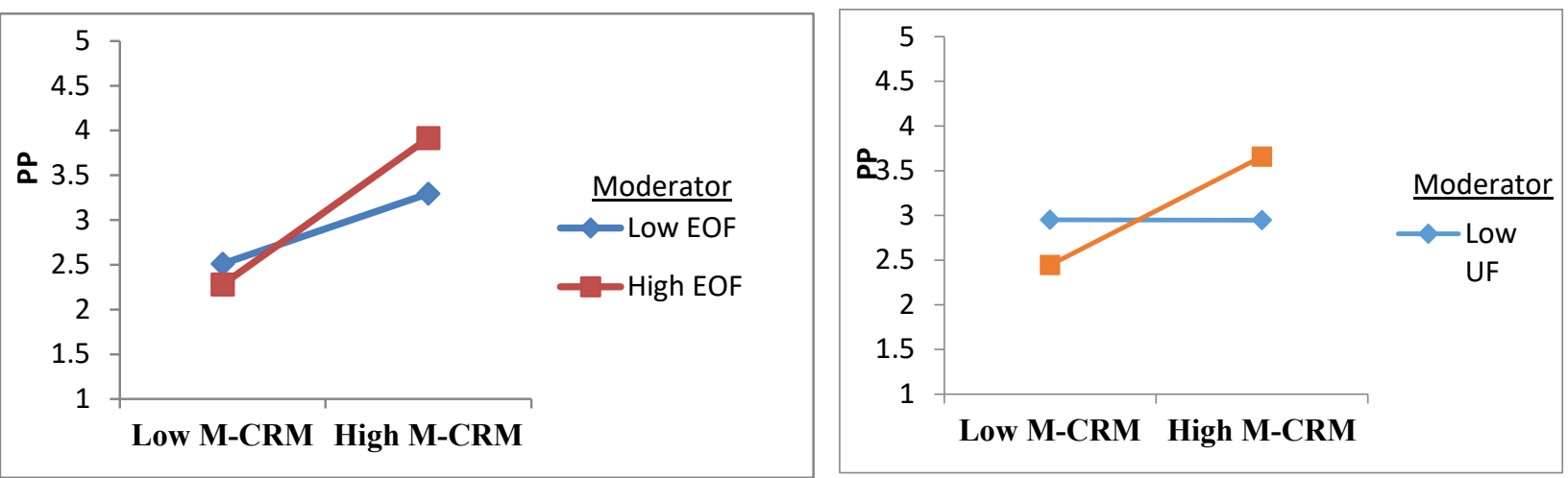

Fig. 3. hypotheses Testing

In terms of direct linkages, the structural model (Table 3) shows that $\mathrm{H} 1$ focused on the influence of M-CRM on post purchase, whereas H2 reported on the impact of Ease of use on post purchase. In relation to H3, the influence of usefulness on postpurchase behavior was also explored. The structural model for H4 (Table-4) stated that ease of use was a moderating factor between M-CRM and post-purchase, whereas the structural model for H5 (Table-5) measured usefulness as a moderating factor between M-CRM and post-purchase. The following conclusions about the influence of post-purchase were gathered from the $\mathrm{H} 1$ study: $\mathrm{T}=2.338, \mathrm{St}=0.311$, and $\mathrm{p}=0.000$ (one-tailed). The $\mathrm{H} 2$ review of the influence of Ease of use on postpurchase yielded the following results: $\mathrm{T}$-value $=3.022, \mathrm{St}=0.544$, and $\mathrm{p}=0.000$ (one-tailed). The H3 research discovered the following results about the influence of usefulness on post-purchase behavior: The study referred to $\mathrm{H} 4$ concerning the moderating role of ese of use between M-CRM and post purchase purpose produced the following results: T-value of 3.087, St, B 0.318 , and p-value of 0.002 (one-tailed); likewise, the study pertains to $\mathrm{H} 4$ concerning the moderating role of ese of use between M-CRM and post purchase purpose obtained the following results: $\mathrm{T}=3.909, \mathrm{St}=0.301$, and $\mathrm{p}=0.000$ (two-tailed). Finally, the research on $\mathrm{H} 5$ the moderating influence of usefulness between M-CRM and post-purchase purpose produced the following findings: $\mathrm{T}=3.910, \mathrm{St}=0.219$, and $\mathrm{p}=0.000$. (One-tailed). Since the $\mathrm{R} 2$ value connected with post purchase was calculated to be 0.477 (Table 3), the findings accounted for roughly $47.7 \%$ of the difference in post purchase, which was consistent with Chin (1998) recommended threshold value of 0.19 . The M-CRM predictor was 0.670 , the EOF predictor was 0.670 , and the UF predictor was 0.465 in terms of F2 values. The amount to which each of the five predictors portrayed the post-purchase was reflected by these numbers. This means that the Q2 value linked with online buying intention was more than zero (0.540), indicating that the model was suitable for prediction (Chin, 2010). Furthermore, the models as a whole goodness of fit and statistical relevant are adequate, with the VIF significance linked with each inner being 2.187, 2.121, and 2.136, respectively, with donations not surpassing 5 (Hair et al., 2017). Table 3 shows the results of the direct effect, which reveal that $\mathrm{H} 1, \mathrm{H} 2$, and $\mathrm{H} 3$ were all supported. The following were the results, in addition to the models related to the moderating influence of ese of use between M-CRM and post purchase (H4): $\mathrm{p}=0.000, \mathrm{~T}$-value $=3.909$, St, B $=0.301$, and Tvalue $=3.909$ (one-tailed). $\mathrm{T}$-value $=3.910, \mathrm{St}, \mathrm{B}=0.219$, and $\mathrm{p}=0.000$, respectively, for the moderating influence of usefulness between M-CRM and post-purchase outcomes (one-tailed). Table 4 shows the results. Similarly, the non-parallel lines in each plot (Figures 4.5) and the increase in the R2 value (Table 5) after considering the interaction effect show a moderating influence. Because of the table's moderating outcome, H4 and H5 were found to be in supported.

\section{Discussion and Conclusion}

The primary objective of this research is to investigate the impact of TAM components and mobile-customer relationship management on post-purchase behavior. Furthermore, the current study offered insight on the extent to which mobile-customer relationship management affected post-purchase behavior via the moderating function of TAM components. Based on this, the first hypothesis (H1) was developed, namely, that mobile-customer relationship management influenced post-purchase behavior favorably. This finding supported the findings of the study done by (Alalwan, 2020). Furthermore, the moderating influence of ease of use and perceived usefulness on the link between mobile-customer relationship management and post-purchase behavior was investigated in relation to such hypotheses, which formed the fourth and fifth hypotheses (H4 \& H5). Due to the lack of consistency in such a connection, such data indicated that the relationship between mobile-customer relationship management and post-purchase behavior should be integrated by ease of use and perceived usefulness (bibi, 2016). Furthermore, results demonstrated a favorable link between TAM components (ease of use and perceived usefulness) 
and post-purchase behavior (H2 \& H3 were supported). These findings suggested that simplicity of use and perceived usefulness influenced post-purchase behavior in a positive way. Furthermore, such findings are consistent with prior empirical investigations done by (Badir \& Andjarwati, 2020; Theocharidis et al., 2020; Khadka \& Maharjan, 2017).

With its use of the technology acceptance model (TAM) to investigate TAM construct (ease of use and perceived usefulness) as a moderator between mobile-customer relationship management (M-CRM) and post-purchase behavior, this paper delivers interesting insights. The results were further tested using the SmartPLS 3 software package. Finally, in this research, hypotheses H4 and H5 were supported, confirming that ease of use and perceived usefulness influence the association between mobile-customer relationship management and post-purchase behavior.

\section{References}

Ahmed, B. S., Amroush, F., \& Maati, M. B. (2019). The Intelligence of E-CRM Applications and Approaches on Online Shopping Industry. In Advanced Methodologies and Technologies in Digital Marketing and Entrepreneurship (pp. 70-82). IGI Global.

Alalwan, A. A. (2020). Mobile food ordering apps: An empirical study of the factors affecting customer e-satisfaction and continued intention to reuse. International Journal of Information Management, 50, 28-44.

Alalwan, A. A., Dwivedi, Y. K., Rana, N. P., \& Williams, M. D. (2016). Consumer adoption of mobile banking in Jordan: Examining the role of usefulness, ease of use, perceived risk and self-efficacy. Journal of Enterprise Information Management.

Al-Gasawneh, J. A., Anuar, M. M., Dacko-Pikiewicz, Z., \& Saputra, J. (2021). The impact of customer relationship management dimensions on service quality. Polish Journal of Management Studies, 23, 24-44.

Alghasawneh, L. A. S., Akhorshaideh, A. H., Alharafsheh, M., Ghasawneh, A., Al-Gasawneh, J. A., \& Al-Hadid, A. Y. (2021). Determinants of Supply Chain Management Practices in Jordanian Pharmaceutical Firms. Solid State Technology, 64(2), 2986-3001.

Almajali, D., Hammouri, Q., Majali, T., Al-Gasawneh, J., \& Dahalin, Z. (2021). Antecedents of consumers' adoption of electronic commerce in developing countries. International Journal of Data and Network Science, 5(4), 681-690.

Al-Momani, K., \& Mohd Noor, N. A. (2009). E-service quality, ease of use, usability and enjoyment as antecedents of eCRM performance: an empirical investigation in Jordan mobile phone services. The Asian Journal of Technology Management, 2(2), 50-64.

Arahita, C. L., \& Hatammimi, J. (2015). Factors affecting the intention to reuse mobile banking service. International Journal of Research in Business and Social Science (2147-4478), 4(4), 15-23.

Awasthi, P., \& Sangle, P. S. (2013). The importance of value and context for mobile CRM services in banking. Business Process Management Journal, 19(6), 864-891.

Badir, M., \& Andjarwati, A. L. (2020). The Effect of E-WOM, Ease of Use and Trust on Purchase Decisions (Study on Tokopedia Application Users). Jurnal Minds: Manajemen Ide dan Inspirasi, 7(1), 39-52.

Bhattacharya, A. (2011). Preeminent Analysis of Customer Relationship Management (CRM). International Journal of Research in Management \& Technology, 1(1), 45-51.

Born, P. H., \& Sirmans, E. T. (2019). Regret in health insurance post-purchase behavior. Risk Management and Insurance Review, 22(2), 207-219.

Cha, J. (2009). Shopping on social networking Web sites: Attitudes toward real versus virtual items. Journal of Interactive Advertising, 10(1), 77-93.

Chin, W. W. (2010). How to write up and report PLS analyses. In Handbook of partial least squares (pp. 655-690). Springer, Berlin, Heidelberg.

Choi, B., Kwon, O., \& Shin, B. (2017). Location-based system: Comparative effects of personalization vs ease of use. Telematics and Informatics, 34(1), 91-102.

Davis, F. D. (1989). Perceived usefulness, perceived ease of use, and user acceptance of information technology. MIS Quarterly, 13(3), 319-340.

Fassott, G., Henseler, J., \& Coelho, P. S. (2016). Testing moderating effects in PLS path models with composite variables. Industrial Management \& Data Systems, 116(9), 1887-1900.

Fornell, C., \& Bookstein, F. L. (1982). Two structural equation models: LISREL and PLS applied to consumer exit-voice theory. Journal of Marketing Research, 19(4), 440-452.

Gani, Z., \& Maung, W. (2020). Mobile Application for Customer Satisfaction (CS), Repurchase Intention (RPI).

Gefen, D., Rigdon, E. E., \& Straub, D. (2011). Editor's comments: an update and extension to SEM guidelines for administrative and social science research. MIS Quarterly, 35(2), 3-14.

Grover, D. (2011). Effective customer relationship management through e-CRM. Viewpoint, 2(1), 27-38.

Hair Jr, J. F., Sarstedt, M., Matthews, L. M., \& Ringle, C. M. (2016). Identifying and treating unobserved heterogeneity with FIMIX-PLS: part I-method. European Business Review, 28(1), 63-76.

Halimi, F. F., Gabarre, S., Rahi, S., Al-Gasawneh, J. A., \& Ngah, A. H. (2021). Modelling Muslims' revisit intention of nonhalal certified restaurants in Malaysia. Journal of Islamic Marketing.

Hamid, A. A., Razak, F. Z. A., Bakar, A. A., \& Abdullah, W. S. W. (2016). The effects of perceived usefulness and perceived ease of use on continuance intention to use e-government. Procedia Economics and Finance, 35, 644-649. 
Hammouri, Q., Al-Gasawneh, J. A., Nusairat, N. M., Hanandeh, A., \& Barakat, S. (2021a). The Determinants of Trust and its Influence on Online Buying Intention: An Empirical Study on Social Commerce in Jordan. Annals of the Romanian Society for Cell Biology, 4522-4539.

Hammouri, Q., Al-Gasawneh, J., Abu-Shanab, E., Nusairat, N., \& Akhorshaideh, H. (2021b). Determinants of the continuous use of mobile apps: The mediating role of users awareness and the moderating role of customer focus. International Journal of Data and Network Science, 5(4), 667-680.

Henseler, J., Ringle, C. M., \& Sarstedt, M. (2015). A new criterion for assessing discriminant validity in variance-based structural equation modeling. Journal of the Academy of Marketing Science, 43(1), 115-135.

Hulland, J. (1999). Use of partial least squares (PLS) in strategic management research: A review of four recent studies. Strategic Management Journal, 20(2), 195-204.

Hussain, A., Mkpojiogu, E. O., \& Yusof, M. M. (2016, August). Perceived usefulness, perceived ease of use, and perceived enjoyment as drivers for the user acceptance of interactive mobile maps. In AIP Conference Proceedings (Vol. 1761, No. 1, p. 020051). AIP Publishing LLC.

Islam, R., Islam, R., \& Mazumder, T. (2010). Mobile application and its global impact. International Journal of Engineering \& Technology (IJEST), 10(6), 72-78.

Jankingthong, W., \& Gonejanart, P. (2012). The relationships of factors affecting post-purchase behavioral intentions in tourism sector. Humanities, Arts and Social Sciences Studies (FORMER NAME SILPAKORN UNIVERSITY JOURNAL OF SOCIAL SCIENCES, HUMANITIES, AND ARTS), 72-90.

Khadka, K., \& Maharjan, S. (2017). Customer satisfaction and customer loyalty. Centria University of Applied Sciences Pietarsaari, 1(10), 58-64.

Kianpour, K., Jusoh, A., Mardani, A., Streimikiene, D., Cavallaro, F., Nor, K. M., \& Zavadskas, E. K. (2017). Factors influencing consumers' intention to return the end of life electronic products through reverse supply chain management for reuse, repair and recycling. Sustainability, 9(9), 1657.

Kotler, K. K. P., \& Manceau, D. (2012). Marketing management 14e. PEARSON FRANCE.

Kuo, Y. F., Wu, C. M., \& Deng, W. J. (2009). The relationships among service quality, perceived value, customer satisfaction, and post-purchase intention in mobile value-added services. Computers in Human Behavior, 25(4), 887-896.

Lee, D. I., Sohn, C., \& Lee, H. (2008). The role of satisfaction and trust in mobile CRM activities. International Journal of Electronic Customer Relationship Management, 2(2), 101-119.

Leong, L. Y., Ooi, K. B., Chong, A. Y. L., \& Lin, B. (2011). Influence of individual characteristics, perceived usefulness and ease of use on mobile entertainment adoption. International Journal of Mobile Communications, 9(4), 359-382.

Li, Y., Duan, Y., Fu, Z., \& Alford, P. (2012). An empirical study on behavioural intention to reuse e-learning systems in rural China. British Journal of Educational Technology, 43(6), 933-948.

Liljander, V., Polsa, P., \& Forsberg, K. (2007). Do mobile CRM services appeal to loyalty program customers. International Journal of E-Business Research (IJEBR), 3(2), 24-40.

Mouri, N. (2005). A consumer-based assessment of alliance performance: An examination of consumer value, satisfaction and post-purchase behavior.

Nusairat, N. M., Alroale, M. A., Al Qeed, M., Al-Gasawneh, J. A., Hammouri, Q., Ahmad, A., \& Abdellatif, H. (2021). USER-GENERATED CONTENT-CONSUMER BUYING INTENTIONS NEXUS: THE MEDIATING ROLE OF BRAND IMAGE. Academy of Strategic Management Journal, 20(4), 1-12.

Nusairat, N., Al-Gasawneh, J., Aloqool, A., Alzubi, K., Akhorshaideh, A., Joudeh, J., \& Ibrahim, H. (2021). The relationship between Internet of things and search engine optimization in Jordanian Tele-Communication Companies: The mediating role of user behavior. International Journal of Data and Network Science, 5(3), 163-172.

Ogunsola, L. A. (2005). Information and communication technologies and the effects of globalization: Twenty-first century "digital slavery" for developing countries - myth or reality?.

Panda, S. (2014). Post purchase consumer complaint behavior: A review of literature. Business Management Dynamics, 4(5), 1.

Pothal, L. K., Tripathy, S., Kumar, K., \& Dash, A. (2021). Study of Customer Relationship Management in Automobile Industry. In Advances in Mechanical Processing and Design (pp. 649-660). Springer, Singapore.

Raajpoot, N., \& Ghilni-Wage, B. (2019). Impact of Customer Engagement, Brand Attitude and Brand Experience on Branded Apps Recommendation and Re-use Intentions. Atlantic Marketing Journal, 8(1), 3.

Rodriguez, M., \& Boyer, S. (2020). The impact of mobile customer relationship management (mCRM) on sales collaboration and sales performance. Journal of Marketing Analytics, 8(3), 137-148.

Saarijärvi, H., Sutinen, U. M., \& Harris, L. C. (2017). Uncovering consumers' returning behaviour: a study of fashion ecommerce. The International Review of Retail, Distribution and Consumer Research, 27(3), 284-299.

Sangle, P. S., \& Awasthi, P. (2011). Consumer's expectations from mobile CRM services: a banking context. Business Process Management Journal, 17(6).

San-Martín, S., Jiménez, N. H., \& López-Catalán, B. (2016). The firms benefits of mobile CRM from the relationship marketing approach and the TOE model. Spanish journal of marketing-ESIC, 20(1), 18-29.

Sarwar, M., \& Soomro, T. R. (2013). Impact of smartphone's on society. European journal of scientific research, 98(2), 216226.

Sekaran, U., \& Bougie, R. (2016). Research methods for business: A skill building approach. John Wiley \& Sons. 
Shaikh, A. A., \& Karjaluoto, H. (2015). Mobile banking adoption: A literature review. Telematics and informatics, 32(1), 129-142.

Shaon, S. K. I., \& Rahman, H. (2015). A theoretical review of CRM effects on customer satisfaction and loyalty. Central European Business Review, 4(1), 23.

Sinisalo, J., Salo, J., Karjaluoto, H., \& Leppäniemi, M. (2007). Mobile customer relationship management: underlying issues and challenges. Business Process Management Journal, 13(6).

Tandon, U., Kiran, R., \& Sah, A. N. (2018). The influence of website functionality, drivers and perceived risk on customer satisfaction in online shopping: an emerging economy case. Information Systems and e-Business Management, 16(1), 5791.

Tehseen, S., Ramayah, T., \& Sajilan, S. (2017). Testing and controlling for common method variance: A review of available methods. Journal of Management Sciences, 4(2), 142-168.

Theocharidis, A. I., Argyropoulou, M., Karavasilis, G., Vrana, V., \& Kehris, E. (2020). An Approach towards Investigating Factors Affecting Intention to Book a Hotel Room through Social Media. Sustainability, 12(21), 8973.

Van der Heijden, H. (2003). Factors influencing the usage of websites: the case of a generic portal in The Netherlands. Information \& Management, 40(6), 541-549.

Wahab, S. (2011). The antecedents of electronic customer relationship management performance (e-CRM) in electronic services. In International Conference on Computer Engineering and Applications (Vol. 2, pp. 250-253).

Wang, J., Cao, B., Yu, P., Sun, L., Bao, W., \& Zhu, X. (2018, July). Deep learning towards mobile applications. In 2018 IEEE 38th International Conference on Distributed Computing Systems (ICDCS) (pp. 1385-1393). IEEE.

Wulfert, T. (2019). Mobile App Service Quality Dimensions and Requirements for Mobile Shopping Companion Apps. Junior Management Science, 4(3), 339-391.

Zhou, T. (2011). An empirical examination of initial trust in mobile banking. Internet Research, 21(5).

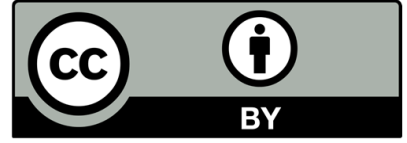

(C) 2022 by the authors; licensee Growing Science, Canada. This is an open access article distributed under the terms and conditions of the Creative Commons Attribution (CC-BY). license (http://creativecommons.org/licenses/by/4.0/). 